\title{
The Uyaijah Ring Structure, Kingdom of Saudi Arabia
}

GEOLOGICAL SURVEY PROFESSIONAL PAPER 774-E

Prepared in cooperation with the Saudi Arabian Ministry of

Petroleum and Mineral Resources
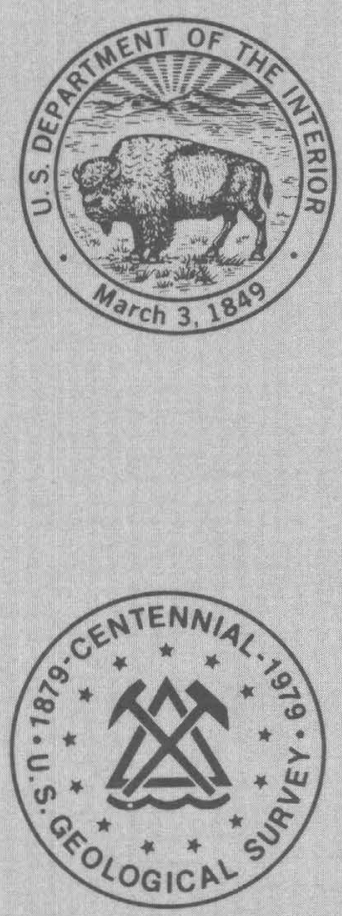



\section{The Uyaijah Ring Structure, Kingdom of Saudi Arabia}

By F. C.W. DODGE

SHORTER CONTRIBUTIONS TO GENERAL GEOLOGY

GEOLOGICAL SURVEY PROFESSIONAL PAPER $774-\mathrm{E}$

Prepared in cooperation with the

Saudi Arabian Ministry of

Petroleum and Mineral Resources

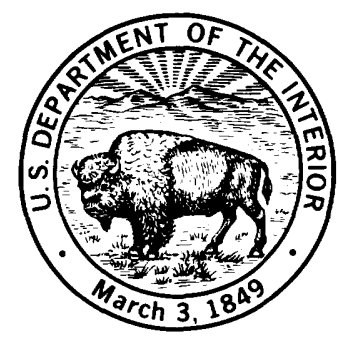

A study of the petrology, structure, and geochemistry

of the plutonic roots of a Precambrian epicontinental caldera 
UNITED STATES DEPARTMENT OF THE INTERIOR

CECIL D. ANDRUS, Secretary

\section{GEOLOGICAL SURVEY}

H. William Menard, Director

Library of Congress Cataloging in Publication Data

Dodge, Franklin C. 1934-

The Uyaijah ring structure, Kingdom of Saudi Arabia.

(Shorter Contributions to General Geology) (Geological Survey Professional Paper 774-E)

Bibliography: p. E15-El7.

1. Intrusions (Geology)--Saudi Arabia. 2. Rocks, Igneous. 3. Petrology-Saudi Arabia. I. Saudi Arabia. Wizarat al-Batrul wa-al-Tharway al-Ma'diniyah. II. Title. III. Series. IV. Series: United States. Geological Survey. Professional Paper 774-E. QE611.5.S33D62

For sale by the Superintendent of Documents, U.S. Government Printing Office

Washington, D.C. 20402

Stock Number 024-001-03148-5 


\section{CONTENTS}

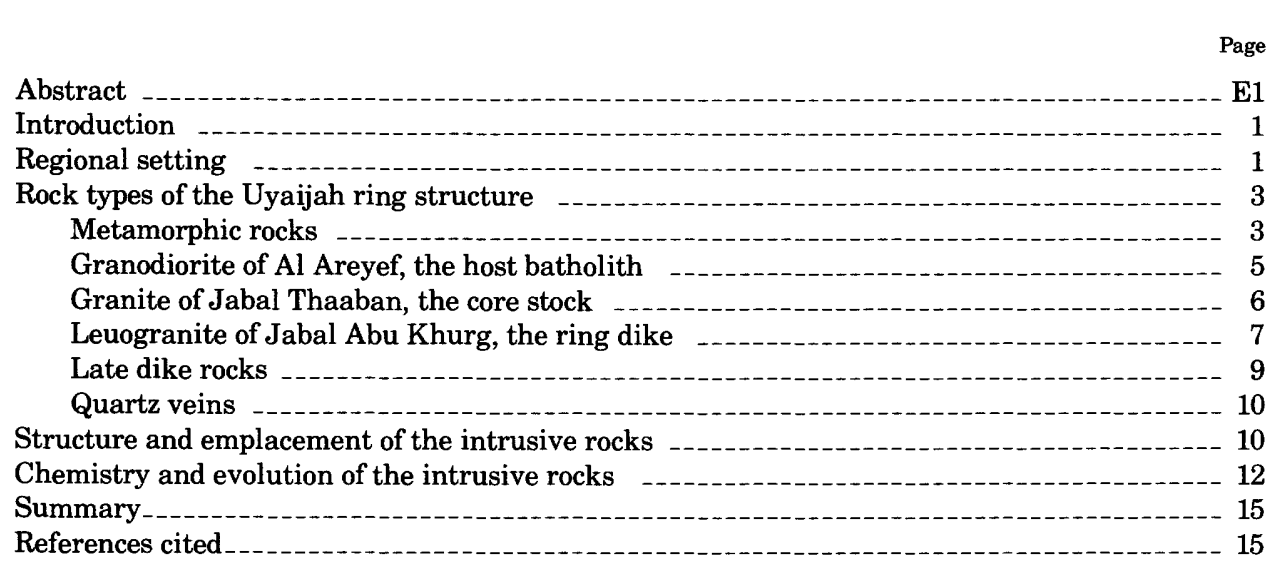

\section{ILLUSTRATIONS}

PLATE 1. Geologic map of part of the Uyaijah ring structure, Buhairan-Abu Khurg area, Kingdom of Saudi Arabia

FIGURE 1. Map of the Arabian Peninsula showing the east edge of the Arabian Shield

2. Photomosaic of the region of the Arabian Shield bounded by $22^{\circ} 30^{\prime}$ and $23^{\circ} 00^{\prime} \mathrm{N}$. lat and $44^{\circ} 00^{\prime}$ and $45^{\circ} 00^{\prime} \mathrm{E}$. long

3. Ternary diagram showing modes of rock types in circular masses

4. Simplified geologic map of the Uyaijah ring structure

5. Ternary diagrams showing modes of individual plutonic rock samples

6. Sketch showing primary foliations in the granodiorite of Al Areyef

7. Ternary diagram showing norms of analyzed plutonic rock samples

8. Graph showing major-element oxide contents of plutonic rocks

9. Graph showing minor-element contents of plutonic rocks -

10. Graphs showing chondrite-normalized rare-earth elements of igneous rocks - -

11. Schematic section showing development of the Uyaijah ring structure

\section{TABLES}

TABLE 1. Analytical data on preintrusive schist and siliceous hornfels

2. Analytical data on granodiorite of Al Areyef

3. Analytical data on granite of Jabal Thaaban

4. Analytical data on altered granite of Jabal Thaaban

5. Analytical data on leucogranite of Jabal Abu Khurg

6. Analytical data on late dike rocks.

7. Selected elemental ratios of igenous rocks of the Uyaijah ring structure 


\title{
THE UYAIJAH RING STRUCTURE, KINGDOM OF SAUDI ARABIA
}

\author{
By F. C. W. DODGE
}

\section{ABSTRACT}

The Precambrian Uyaijah ring structure is one of several batholithic masses in the eastern part of the Arabian Shield. A central core stock and a ring dike have been intruded into the circular batholith, their form being controlled by the early developed primary foliation of the batholith.

Analyses for major-element oxides and trace-element data indicate that the central core stock resulted by continous differentiation of the batholithic magma with fractional crystallization and removal of hornblende. In contrast, the chemical data suggest that the ring dike crystallized from magma of ternary minimum composition from which great amounts of feldspar were removed.

Although related extrusive volcanic rocks are not exposed in the general region, the ring structure is believed to be the plutonic analog of an epicontinental caldera.

\section{INTRODUCTION}

The Uyaijah ring structure is part of a large igneous complex in central Saudi Arabia near the eastern edge of the Arabian Shield (fig. 1). The structure consists of metamorphic rocks and a large granodiorite batholith that have been intruded by a core-forming granite stock and later by a circular leucogranite ring dike. The entire assemblage of intrusive rocks is part of a major Precambrian magmatic sequence of calc-alkaline plutonic rocks abundant in the northeastern part of the Arabian Shield (Greenwood and Brown, 1973).

Units of the ring structure are part of a great number of granodiorite to granite plutonic bodies that commonly occur as nearly circular intrusive masses or as ring complexes and form the youngest major Precambrian group of igneous rocks of the Arabian Shield (Fleck and others, 1976). Similar ring complexes occur to the west in Sudan (Vail, 1972; Neary and others, 1976), forming an igneous province of more than $3 \mathrm{x}$ $10^{6} \mathrm{~km}^{2}$.

The Uyaijah ring structure has received considerable attention because of the discovery of anomalous amounts of tungsten and molybdenum in wadi sediments in the general area (Whitlow, 1968a, b, 1971; Theobald, 1971; Theobald and Allcott, 1975; Flanigan and Andreasen, 1975). Locally mineralized metamorphic rocks and late molybdenite-bearing quartz veins are sources for the anomalous metal content (Dodge, 1973; Dodge and Helaby, 1975).

Field and analytical data collected during and following studies of mineralization are presented in this report. Analyses of major-element oxides were carried out in U.S. Geological Survey Analytical Laboratories, Washington, D.C., using a method described by Shapiro and Brannock (1962) supplemented by atomic absorption. Twenty-eight elements were determined by instrumental neutron activation analysis using the U.S. Geological Survey's Denver TRIGA reactor, following procedures described by Gordon and others (1968) and Hertogen and Gijbels (1971). Modal analyses were done in U.S. Geological Survey laboratories, Jeddah, Saudi Arabia, by counting a minimum of 1,000 points on appropriate sized grids superimposed on large stained rock slabs (Jackson and Ross, 1956; Laniz and others, 1964). Bulk rock densities were determined in Jeddah laboratories, using a large Westphal or a Jolly balance.

This study was done by the U.S. Geological Survey in accordance with an agreement with the Ministry of Petroleum and Mineral Resources, Kingdom of Saudi Arabia.

\section{REGIONAL SETTING}

The region of the Arabian Shield bounded by $22^{\circ} 30^{\circ}$ and $23^{\circ} \mathrm{N}$. lat and $44^{\circ}$ and $45^{\circ} \mathrm{E}$. long (fig. 2) is underlain by Precambrian calc-alkaline plutonic and preplutonic metamorphic rocks that have been intruded by a variety of felsic and mafic dikes and by quartz and carbonate-rich veins. A thin veneer of Quaternary surficial debris consisting of wadi sediments, eolian dune sands, poorly sorted pediment materials, and talus blankets much of the area.

Jackson and others (1963), Whitlow (1968a, b), and Lacombe and Letalenet (1970) have mapped the metamorphic rocks in the region as parts of the Halaban or Murdama Formations, both redesignated as groups by Schmidt and others (1973). The Halaban Group is a widespread sequence of dominantly metavolcanic rocks; the Murdama Group is a sequence 


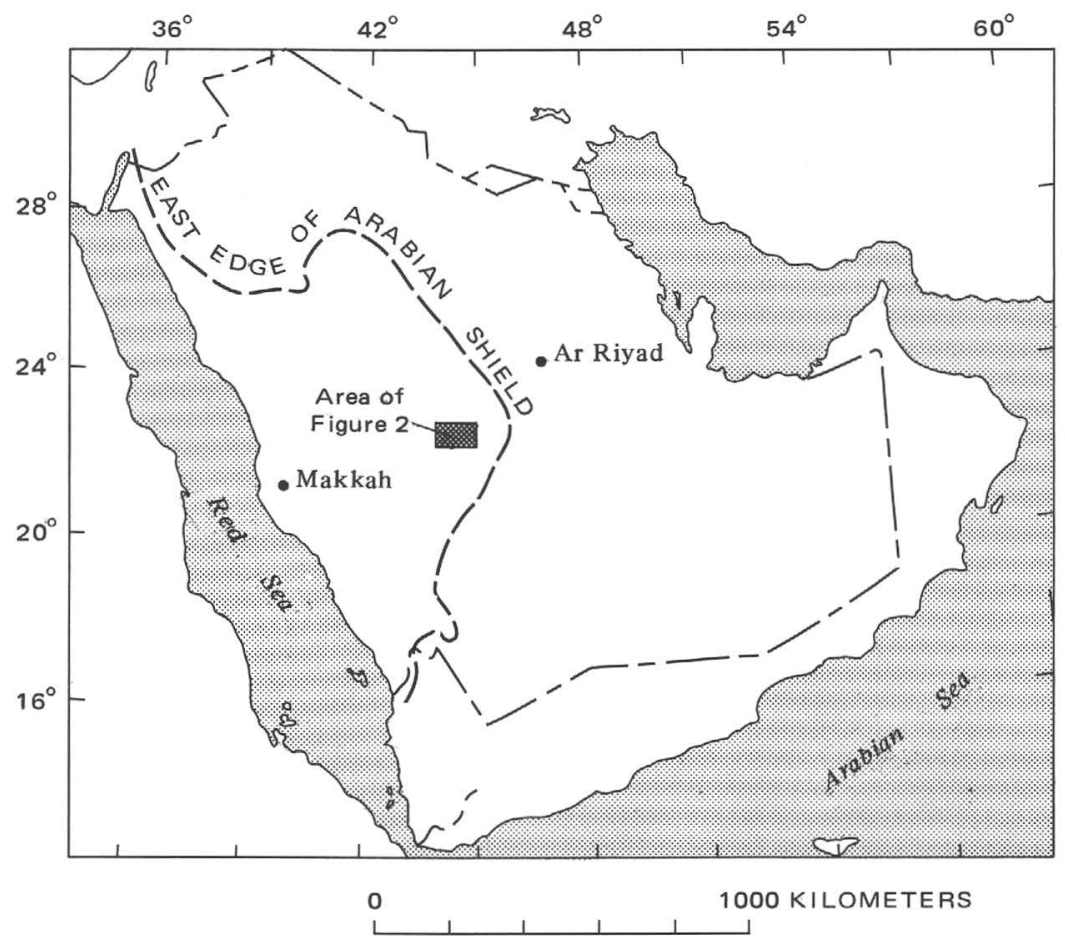

Figure 1.-Map of the Arabian Peninsula showing the east edge of the Arabian Shield. The region of the shield bounded by $22^{\circ} 30^{\prime}$ and $23^{\circ} \mathrm{N}$. lat and $44^{\circ}$ and $45^{\circ} \mathrm{E}$. long (heavily shaded) is shown in figure 2 .

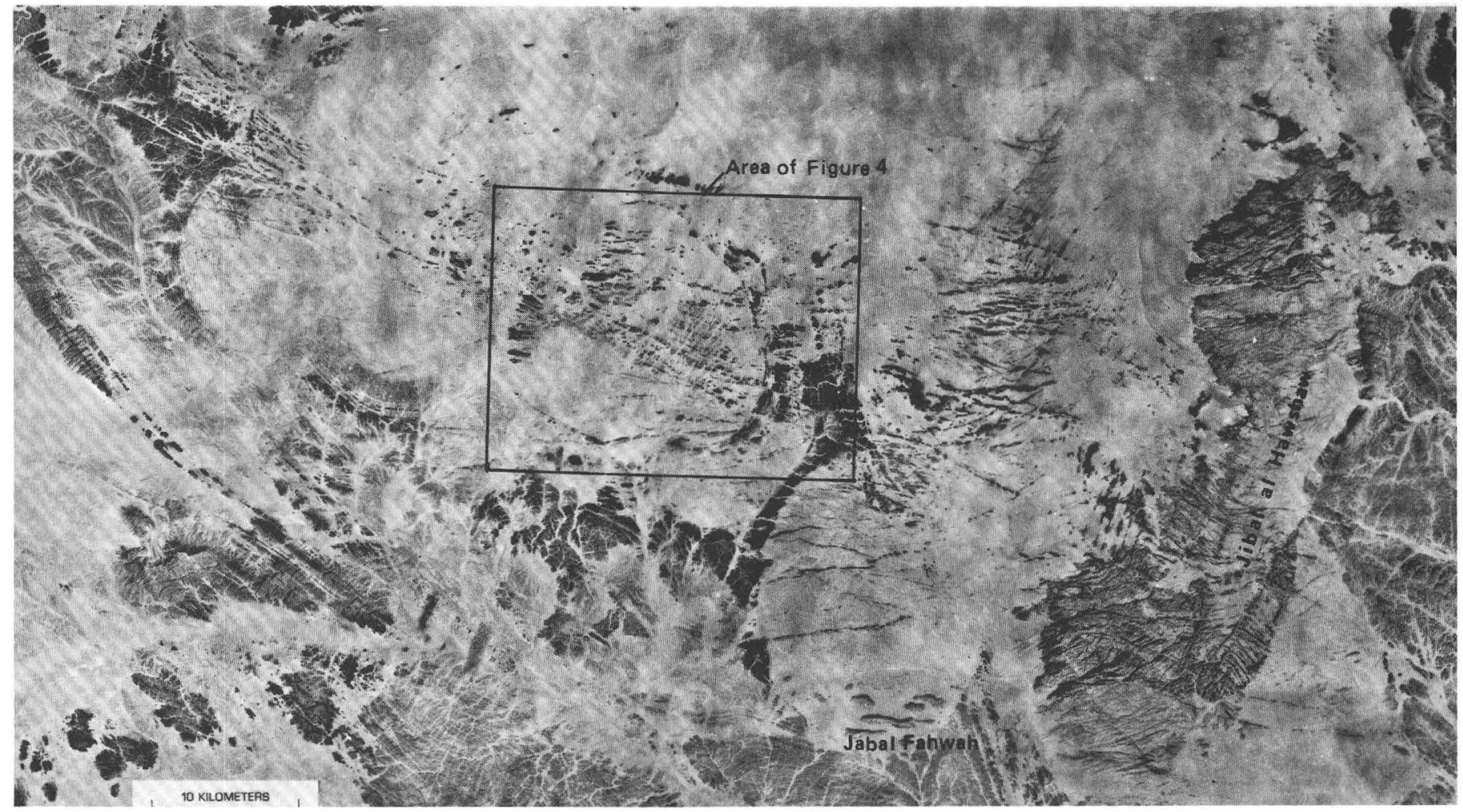

Figure 2.-Photomosaic of the region of the Arabian Shield bounded by $22^{\circ} 30^{\prime}$ and $23^{\circ} \mathrm{N}$. lat and $44^{\circ}$ and $45^{\circ}$ E. long showing the Uyaijah ring structure (circular area slightly left of center of mosaic). 
of dominantly metamorphosed detrital sedimentary rocks that unconformably overlies the Halaban.

A composite batholith makes up a large mountain range in the eastern part of the region; Jibal al Hawshah is the most prominent feature. The batholith consists of two large granite plutons separated by smaller, older bodies of more mafic igneous rocks.

Large circular masses, crudely alined along a N. $60^{\circ}$ W. trend, extend from immediately west of Jibal al Hawshah to near the western margin of the region. The southeasternmost mass is composed of porphyritic granite (fig. 3), well exposed near its southern edge in a series of 250-m-high elongate domelike inselbergs, the most prominent of which is Jabal Fahwah. Foliations in the granite in this area parallel the circular form of the mass. A complex of younger, massive felsic plutonic rocks intrudes the northeastern part of the mass. Immediately northwest of this southeastern mass is the circular body that contains the Uyaijah ring structure (fig. 4). The host plutonic rock of the ring structure, though porphyritic granodiorite, is correlative with the granite at Jabal Fahwah. An arcuate form to the west

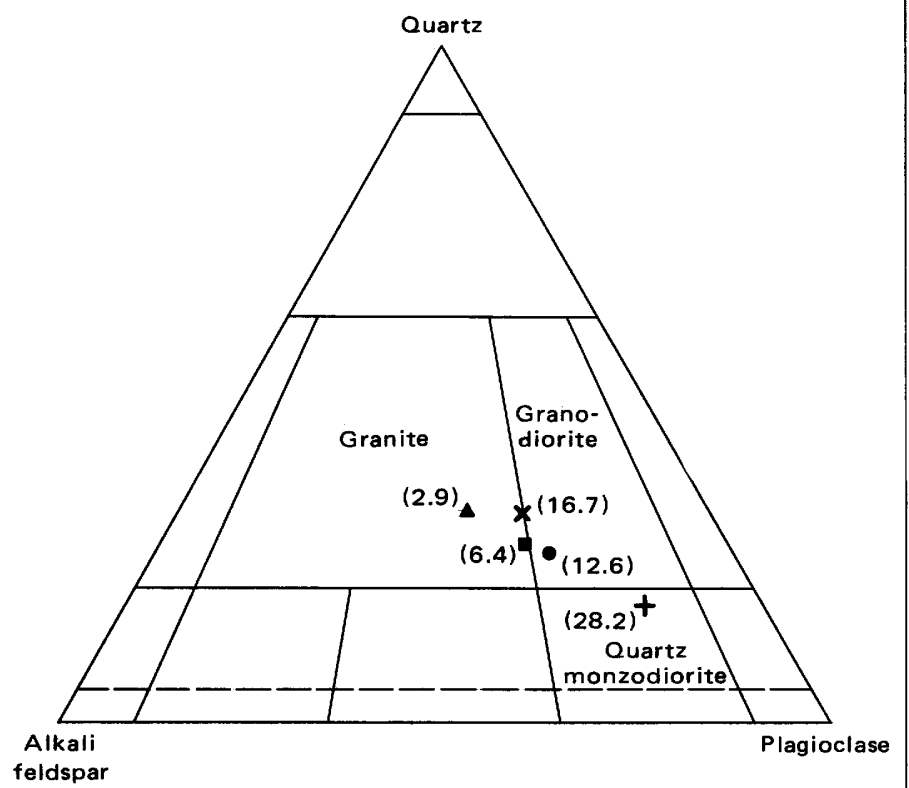

EXPLANATION

+ Sample of rock from northwestern
mass
$\times$ Sample of rock from Jabal
Fahwah
- Average of 22 modes of grano-
diorite of Al Areyef
- Average of 10 modes of granite of
Jabal Thaaban
Average of 14 modes of leuco-
granite of Jabal Abu Khurg

Figure 3.-Ternary diagram showing modes of rock types in circular masses. Volume percent of mafic minerals in parenthesis. Classification and nomenclature recommended by the IUGS Subcommission of the Systematics of Igneous Rocks. of the Uyaijah ring structure is suggestive of a third circular mass, but no plutonic bedrock is exposed within the arc, which is composed of metamorphic rocks. Northwest of this arc is another mass, poorly exposed. Equigranular quartz monzodiorite (fig. 3), distinctly different from the porphyritic rocks to the east, crops out in its northern part.

The plutonic rocks of the region are believed to have cooled 560 to 610 m.y. ago during the last major period of magmatic activity in the shield, in the first phase of the Pan-African event (Fleck and others, 1976).

Metamorphic and plutonic rocks are cut by a series of east-west to northwest-trending fractures that exhibit dominant left-lateral offsets. The fractures, first described by Brown and Jackson (1960), are a part of the Najd fault system (Delfour, 1970) that apparently extends across the entire northern part of the shield. Hypabyssal dikes and veins that follow the fracture trends intrude all the older rocks in the region. Age relations between mafic and felsic dikes, while generally uniform locally, are inconsistent regionally. For example, mafic dikes cut felsic dikes in the Uyaijah ring structure, whereas mafic dikes invariably precede their felsic counterparts in the Jibal al Hawshah region.

\section{ROCK TYPES OF THE UYAIJAH RING STRUCTURE}

The mass containing the Uyaijah ring structure is the only circular plutonic mass in the region with a ring dike and a separate central core; it is also the best exposed of the masses. Compared with many ring structures elsewhere in the world (see, for example, Chapman, 1942; Oftedahl, 1953; Jacobson and others, 1958; Eggler, 1968; Oldershaw, 1974; Bussell and others, 1976), the Uyaijah structure is relatively simple, consisting of only three major plutonic units and associated metamorphic rocks (fig. 4) cut by later dikes and veins (pl. 1).

\section{METAMORPHIC ROCKS}

Prebatholithic metamorphic rocks occur in a large mass in the southwestern part of the area, in bowlike belts of septa at or near ring-dike contacts in the eastern half of the area, in a large septum that separates the Uyaijah structure from the circular mass to the southeast, and locally in large inclusions in the plutonic rocks.

Fine-grained quartz hornfels and biotite schist derived from shales or siltstones are the most abundant metamorphic rocks, except in the southwestern part of the area. Near the contact with the ring dike the hornfels is interlayered with, and grades into, the schist. Foliation in the schist is generally nearly verti- 

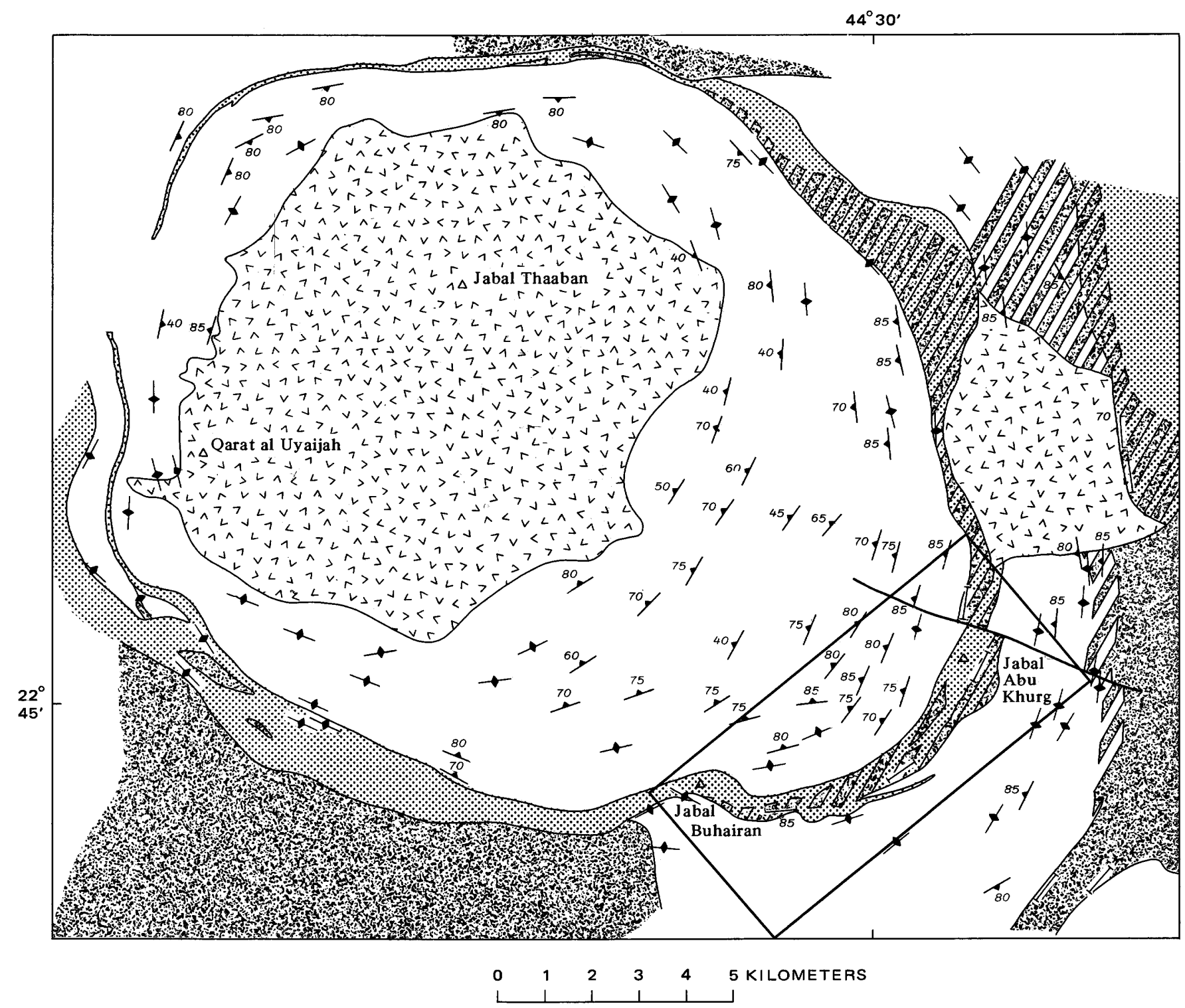

\section{EXPLANATION}

Areas where metamorphic and granitic rocks cannot be separated at map scale shown by cross-hatched pattern of respective units.

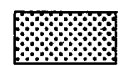

Leucogranite of Jabal Abu Khurg

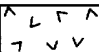

Granite of Jabal Thaaban

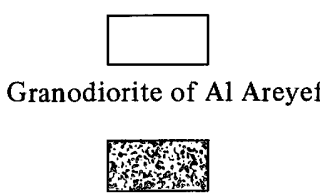

Metamorphic rocks

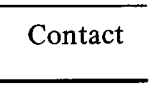

Fault
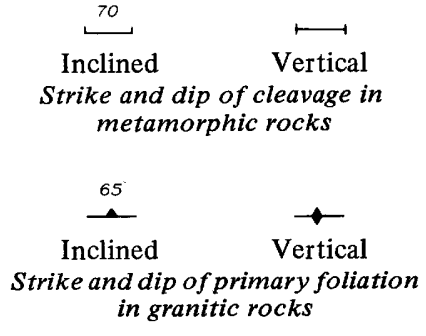

in granitic rocks

FIGURE 4.-Simplified geologic map of the Uyaijah ring structure. Outlined area shows approximate area of plate 1. 
cal and is parallel to ring dike-metamorphic rock contacts. Bedding, also parallel to the contacts, is common in outcrops of hornfels but is rarely discernible in the schist. The siliceous hornfels and mica schist are dark rocks consisting chiefly of quartz, green biotite, intermediate plagioclase (andesine), and, in some rocks, green hornblende. Microcline, epidote, carbonate minerals, zircon, sphene, and opaque minerals are present in subordinate amounts. Chlorite is common as an alteration product of biotite. Analytical data on siliceous hornfels and biotite schist are given in table 1.

TABLE 1.-Analytical data on preintrusive schist and
siliceous hornfels
$\begin{gathered}\text { [Chemical analyses by rapid rock method; } \\ \text { analyst, P. L. D. Elmore. }\end{gathered}=$ standard deviation]

\begin{tabular}{|c|c|c|c|}
\hline \multicolumn{4}{|c|}{ Chemical analyses (weight percent) } \\
\hline \multirow[t]{2}{*}{$\begin{array}{l}\mathrm{SiO}_{2} \\
\mathrm{Al}_{2} \mathrm{O}_{3} \\
\mathrm{Fe}_{2} \mathrm{O}_{3} \\
\mathrm{FeO}_{3} \\
\mathrm{MgO} \\
\mathrm{CaO} \\
\mathrm{Na}_{2} \mathrm{O} \\
\mathrm{K}_{2} \mathrm{O} \\
\mathrm{H}_{2} \mathrm{O}+ \\
\mathrm{H}_{2} \mathrm{O}- \\
\mathrm{TiO}_{2} \\
\mathrm{P}_{2} \mathrm{O}_{5} \\
\mathrm{MnO}^{\mathrm{CO}} \\
\mathrm{CO}_{2}\end{array}$} & $\begin{array}{r}-1 \\
-\end{array}$ & $\begin{array}{r}59.8 \\
15.3 \\
3.5 \\
3.0 \\
3.8 \\
4.3 \\
2.8 \\
2.5 \\
1.9 \\
.29 \\
.76 \\
.33 \\
.09 \\
1.1\end{array}$ & $\begin{array}{r}70.0 \\
14.8 \\
1.8 \\
1.6 \\
1.4 \\
4.4 \\
4.0 \\
.42 \\
.69 \\
.04 \\
.44 \\
.15 \\
.06 \\
.04\end{array}$ \\
\hline & Total & 99.5 & $\overline{99.9}$ \\
\hline
\end{tabular}

Density data $\left(\mathrm{g} / \mathrm{cm}^{3}\right)$ based on 10 samples:

\begin{tabular}{l} 
Density data $\left(\mathrm{g} / \mathrm{cm}^{3}\right)$ based on 10 samples: \\
\hline $\begin{array}{l}\text { Mean } \\
\text { Range } \\
\sigma\end{array}$
\end{tabular}

Sparse metaconglomerate, in beds consisting largely of lithic clasts and fragments of vein quartz as much as $2 \mathrm{~cm}$ in diameter in a matrix of siliceous hornfels, is interlayered with the other metamorphic rocks. Calchornfels, resulting from thermal metamorphism of limy shales in the original sedimentary sequence, occurs in thin discontinuous bands or lenses, generally less than $10 \mathrm{~cm}$ thick, that are interlayered with the siliceous hornfels or with the schist at a few localities. The calc-hornfels is a massive light-colored rock consisting principally of garnet, clinozoisite, and diopside with lesser amounts of quartz, carbonate, calcic plagioclase (bytownite), sphene, pistacite, and powellite.

Massive dark-colored amphibolite is exposed in the southwestern part of the area. In the eastern part of this area, slivers of amphibolite have been faulted into isoclinally folded, sheared biotite schist. The amphibolite is composed largely of fine- to medium-grained anhedral to subhedral colorless to blue-green amphibole (hornblende-actinolite) and subhedral medium-grained polysynthetic-twinned plagioclase. The feldspar ranges compositionally from labradorite $\left(A_{50}\right)$ to bytownite $\left(A_{75}\right)$ and has undergone varying degrees of sericitization. Minerals present in trace amounts include epidote, biotite, and opaque and translucent iron oxides. Two densities determined on amphibolite samples are 3.069 and $3.104 \mathrm{~g} / \mathrm{cc}$.

\section{GRANODIORITE OF AL AREYEF, THE HOST BATHOLITH}

The oldest igneous rock unit in the Uyaijah ring structure is the granodiorite of $\mathrm{Al}$ Areyef (fig. 4). Al Areyef is the entire area of plain and isolated inselbergs occupied by the ring structure. Outcrops of the granodiorite define a batholith covering a total area of about $180 \mathrm{~km}^{2}$.

The granodiorite of $\mathrm{Al}$ Areyef ranges in composition from quartz monzodiorite through granodiorite to granite (fig. 5) and has a color index ranging from 7 to 22 (table 2); it has the same general appearance regardless of its composition. Despite the large compositional variation of the grandiorite, there is no evidence of large-scale systematic compositional zoning of the batholith.

Conspicuous tabular phenocrysts of microcline are the most striking feature of the granodiorite. They are commonly $2 \mathrm{~cm}$ long and are set in a medium-grained hypidiomorphic granular groundmass. The groundmass minerals are anhedral quartz, subhedral polysynthetic twinned generally unzoned plagioclase (An27-An37), anhedral microcline, subhedral green biotite, and accessory amounts of sphene, apatite, epidote, and opaque minerals. Green hornblende is present in much of the granodiorite.

Commonly the granodiorite has a conspicuous primary foliation marked by planar alinement of the tabular microcline phenocrysts, by alinement of mafic minerals, or by parallel orientation of lenticular or discoid mafic inclusions. Lineation is not discernible. Jointing generally is only weakly developed.

Where exposed, contacts of the granodiorite with other rock units are generally sharp, and there is little evidence of reaction between the granodiorite and adjacent rocks. The batholith is clearly intrusive into the metamorphic rocks. In the southeastern part of the Uyaijah ring structure, steeply dipping sheetlike bodies of the granodiorite have intruded siliceous hornfels. The area has been mapped as a mixture of the two rock types (fig. 4), and the contact with the main mass of metamorphic rocks has been placed on the basis of the last occurrence of the granodiorite. 
rock. It ranges in composition from grandiorite to granite and invariably contains more plagioclase than either quartz or potassium feldspar (fig. 5; table 3). Both quartz and plagioclase occur in a wide range of grain sizes. Jaggedly bounded anhedral grains of quartz commonly display undulose or patchy extinction. Plagioclase occurs in polysynthetically twinned concentrically zoned subhedral to euhedral grains having an average composition of calcic oligoclase. Potassium feldspar is in large commonly grid-twinned anhedral grains, sporadically associated with myrmekite. Small ragged flakes of olive-brown biotite are disseminated throughout the rock. Minor accessories include opaque grains, epidote minerals, apatite, zircon, white mica, and, rarely, sphene.

Foliation in the granite is absent or very weakly defined by alinement of biotite grains. Joints are widely spaced and are preferentially oriented N. $70^{\circ} \mathrm{W}$.; they control the marked northwesterly physiographic trend through the middle of the ring structure.

Pervasive alteration of the granite is widespread in the central stock; most samples show minor alteration effects, including varying degrees of sericitization of plagioclase, small sericite-filled fractures, and sericitic coatings of grain boundaries. The most intensely altered rocks occur in a crudely defined 3-km-wide N. $70^{\circ}$ W.-trending belt through the middle of the stock. From a distance, altered rocks appear dark brown where exposed, whereas relatively unaltered counterparts are white or light gray. The altered rocks themselves are pink. In contrast to other areas, joints in highly altered rocks are closely spaced, but generally follow the dominant joint trend manifest elsewhere in the granite. Although altered rocks underlie broad expanses, they also occur in narrow bands $1 \mathrm{~cm}$ to $1 \mathrm{~m}$ wide, alternating with unaltered rocks.

Altered rocks are typically enriched in muscovite; biotite is absent or chloritized; opaque minerals are oxidized; and plagioclase and rarely potassium feldspar are sericitized. Minor amounts of oxidized pyrite, carbonate, and epidote are present in some altered rocks. Development of clay minerals and potassium feldspar enrichment are not alteration features.

A slight decrease of specific gravity is a consequence of the alteration (tables 3 and 4). On a constant volume basis, $\mathrm{K}_{2} \mathrm{O}, \mathrm{MnO}$, and $\mathrm{CO}_{2}$ have been added, $\mathrm{SiO}_{2}$ has remained nearly constant, $\mathrm{Na}_{2} \mathrm{O}$ and $\mathrm{Al}_{2} \mathrm{O}_{3}$ have been only slightly depleted, and other oxides have been highly depleted; iron has been further oxidized. Meyer and Hemley (1967, p. 210) have noted that addition of potassic oxide, but only small changes in amounts of alumina are common features of sericitic alteration, particularly where sericite is formed at the expense of plagioclase without destruction of potassium feldspar.
TABLE 3.-Analytical data on granite of Jabal Thaaban [Chemical analyses by rapid rock method, analyst, P. L. D. Elmore. Neutron-activation analyses by $\mathrm{H}$. T. Millard, Jr. and R. J. Knight. $\sigma=$ standard deviation]

\begin{tabular}{|c|c|c|c|}
\hline Sample No. ---1- 504 & 535 & 512 & 121 \\
\hline \multicolumn{4}{|c|}{ Chemical analyses (weight percent) } \\
\hline 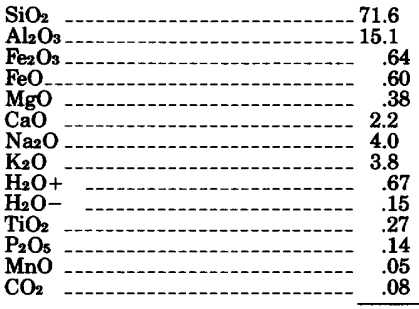 & $\begin{array}{c}72.0 \\
15.1 \\
.75 \\
.68 \\
.48 \\
1.6 \\
3.7 \\
3.9 \\
.64 \\
.04 \\
.30 \\
.15 \\
.02 \\
.01\end{array}$ & $\begin{array}{c}72.8 \\
15.1 \\
.60 \\
.36 \\
.27 \\
1.6 \\
4.0 \\
3.9 \\
.54 \\
.07 \\
.20 \\
.09 \\
.04 \\
.07\end{array}$ & $\begin{array}{r}73.4 \\
14.8 \\
.40 \\
.64 \\
.41 \\
1.8 \\
3.6 \\
4.0 \\
.79 \\
.04 \\
.16 \\
.06 \\
.02 \\
.07 \\
\end{array}$ \\
\hline Total & $\overline{99.4}$ & 99.7 & $\overline{100.2}$ \\
\hline
\end{tabular}

\begin{tabular}{|c|c|c|c|c|}
\hline \multicolumn{5}{|c|}{ Norms (weight percent) } \\
\hline & 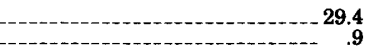 & $\begin{array}{r}32.2 \\
2.3\end{array}$ & $\begin{array}{r}31.5 \\
1.8\end{array}$ & 33.0 \\
\hline & 22.7 & 23.4 & 23.3 & 23.8 \\
\hline & 34.2 & 31.7 & 34.2 & 30.7 \\
\hline an & 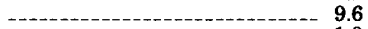 & 7.0 & 7.0 & 8.1 \\
\hline & ----------------------------- 1.0 & 1.2 & .7 & 1.0 \\
\hline fs & 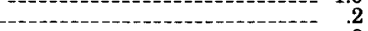 & .2 & $\ddot{-}$ & .6 \\
\hline & -2.9 & 1.1 & .8 & .6 \\
\hline & 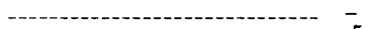 & - & .09 & - \\
\hline il . &.- .5 & .6 & .4 & 3 \\
\hline ap & 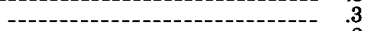 & .4 & .2 & .1 \\
\hline cc & .2 & .02 & .2 & .2 \\
\hline
\end{tabular}
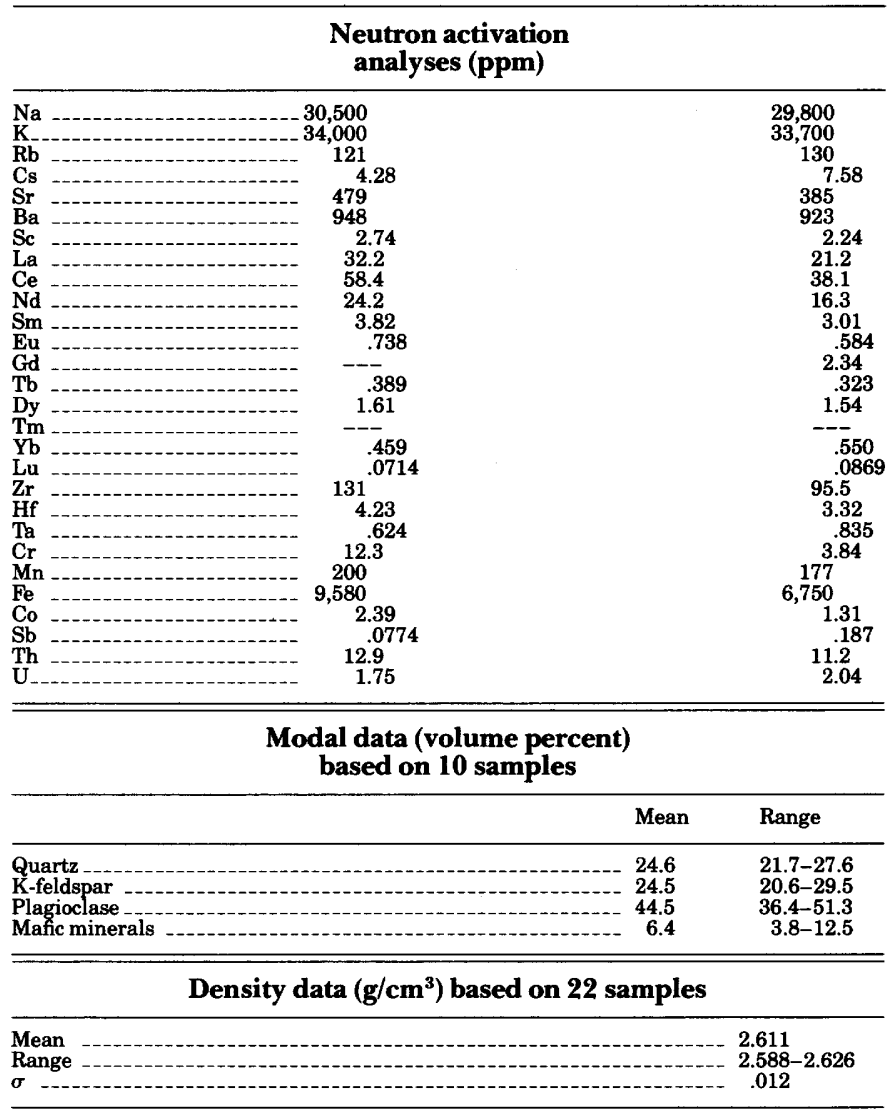

\section{LEUCOGRANITE OF JABAL ABU KHURG, THE RING DIKE}

The leucogranite of Jabal Abu Khurg makes up the ring dike of the Uyaijah structure (fig. 4; pl. 1). Jabal Abu Khurg, a 1,200-m-high mountain, is the most prominent topographic feature of the general area. The 
at one locality, weak foliation parallel to the dike walls is distinguished by a general elongation of mineral grains and clots of grains. Joints in the leucogranite are widely spaced and tend to follow the general ringdike configuration.

\section{LATE DIKE ROCKS}

Steeply dipping generally northwest- to east-westtrending dikes intrude the three major plutonic units and metamorphic rocks of the Uyaijah structure. These dikes are abundant in the Buhrairan-Abu Khurg area (pl. 1).

Dikes of a variety of fine- to medium-grained granitic rocks, aplites, and pegmatites range in width from a few centimeters to more than $10 \mathrm{~m}$ and are as much as hundreds of meters long; quantitatively, these dikes are of little significance. Most likely, many are latestage products related to consolidation of the older plutonic masses.

Felsic and mafic hypabyssal dikes that cut rocks throughout the entire region are prominent within the Uyaijah structure. Both types are intrusive into all major rock units, but only minor effects of baking or alteration by the dikes on their hosts are apparent.

Two nearly east-west-trending felsic dikes form conspicous through-going wall-like features. The dikes are vertical, range in width from 0.5 to nearly $10 \mathrm{~m}$, and are each more than $10 \mathrm{~km}$ long. They consist of fairly uniform massive orange-brown porphyritic rocks. The rock is made up of 15 to 20 percent of medium-grained phenocrysts of euhedral to subhedral embayed quartz, elongate tabular euhedral to subhedral unzoned plagioclase of sodic andesine composition, euhedral to subhedral perthitic alkali feldspar, and sparse epidote euhedra and opaque grains. The groundmass generally consists of a fine-grained to microcrystalline mixture of anhedral quartz, plagioclase, alkali feldspar, green hornblende, opaque grains, sericite, and carbonate. According to Rittmann's chemical classification (1952), one of the felsic dike samples analyzed (table 6, No. 096) is a rhyolite.

At some localities along its extent, one of the felsic dikes is cut by younger steep-sided mafic dikes, clearly demonstrating the relation between the two types of hypabyssal dikes. The dark-colored mafic dikes are ubiquitous in the area. Individual dikes range in thickness from a few centimeters to more than $2 \mathrm{~m}$ and commonly can be traced for distances of a few kilometers.

The mafic dikes have diverse compositions, as illustrated by a large range of bulk densities and standard deviation from the mean density (table 6 ). The densities may be somewhat influenced by degree of vesicularity; nonetheless, composition is undoubtedly the
TABLE 6.-Analytical data on late dike rocks [Chemical analyses by rapid rock method, analyst, P. L. D. Elmore. Neutron activation analyses by H. T. Millard, Jr, and R. J. Knight. $\sigma=$ standard deviation]

\begin{tabular}{lcc}
\hline Sample $\mathrm{No}$. & 096 & 114 \\
\hline \multicolumn{3}{c}{ Chemical analyses } \\
\hline
\end{tabular}

\begin{tabular}{|c|c|c|}
\hline \multicolumn{3}{|c|}{ Norms (weight percent) } \\
\hline $\mathrm{Q} \ldots$ & 36.8 & 9.9 \\
\hline $\mathrm{C}-(-1$, & 2.0 & 8.8 \\
\hline $\begin{array}{l}\text { or } \\
\text { ab }\end{array}$ & $\begin{array}{l}26.3 \\
25.6\end{array}$ & $\begin{array}{l}12.3 \\
29.8\end{array}$ \\
\hline an & $\begin{array}{l}4.6 \\
8\end{array}$ & 9.3 \\
\hline fs & & 6.7 \\
\hline $\begin{array}{l}\mathrm{mt} \\
\mathrm{hm}\end{array}$ & .8 & $\begin{array}{r}5.7 \\
---\end{array}$ \\
\hline il --..- & .2 & 4.5 \\
\hline ap & 2.07 & $\begin{array}{c}2.0 \\
10.1\end{array}$ \\
\hline mg & & 1.1 \\
\hline \multicolumn{3}{|c|}{ Neutron activation analyses (ppm) } \\
\hline -.-- & 22,600 & 24,400 \\
\hline $\mathrm{K}_{\mathrm{Bh}}$ & 33,500 & 14,300 \\
\hline $\begin{array}{ll}\mathrm{Kb} \\
\mathrm{Cs}\end{array}$ & 3.39 & 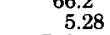 \\
\hline $\mathrm{Sr}$ & 51.4 & 758 \\
\hline $\mathrm{Ba}$ & 195 & 527 \\
\hline Sc-..... & 2.44 & $\begin{array}{l}13.8 \\
46.0\end{array}$ \\
\hline $\mathrm{Ce}-$ & 44.6 & 88.5 \\
\hline Nd & 22.6 & 42.4 \\
\hline $\mathrm{Sm}_{\mathbf{E u}}$ & 5.46 & 8.12 \\
\hline Gd $-\cdots$ & 4.81 & 7.70 \\
\hline Dy & 5.06 & 5.33 \\
\hline $\operatorname{Tm}$ & .420 & \\
\hline $\begin{array}{l}\mathrm{Yb} \\
\mathrm{Lu}\end{array}$ & $\begin{array}{l}.43 \\
.335\end{array}$ & .4. \\
\hline $\mathrm{Zr}_{\mathrm{H}}-\mathrm{f}^{-}$ & 132 & 268.24 \\
\hline Ta & 3.93 & 4.23 \\
\hline 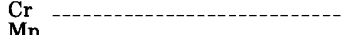 & 10.5 & 53.9 \\
\hline $\begin{array}{l}\mathrm{Mn} \\
\mathrm{Fe}\end{array}$ & 9.030 & $\begin{array}{r}1,110 \\
78,000\end{array}$ \\
\hline Co & .744 & 33.3 \\
\hline 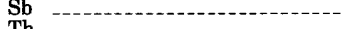 & .417 & .580 \\
\hline $\begin{array}{l}\text { Th } \\
\text { U }\end{array}$ & ${ }_{8.17}^{22.2}$ & $\begin{array}{l}5.03 \\
1.45\end{array}$ \\
\hline
\end{tabular}

Density data $\left(\mathrm{g} / \mathrm{cm}^{3}\right)$ based on 4 samples of felsic dike rocks
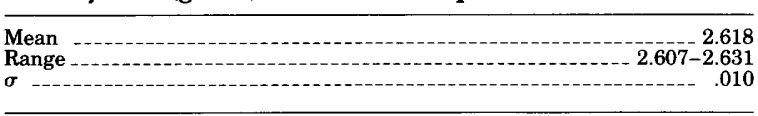

Density data $\left(\mathrm{g} / \mathrm{cm}^{3}\right)$ based on 14 samples of mafic dike rock

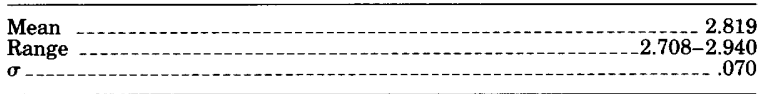

more critical determinant. Millimeter-sized vesicles are commonly filled with a microcrystalline to cryptocrystalline mixture of chlorite, carbonate, zeolite, and quartz. Plagioclase, the most abundant mineral in the mafic rocks, ranges from calcic oligoclase to calcic labradorite but within a single specimen shows little variability. Phenocrysts, largely euhedral plagioclase but 
including oxyhornblende and opaque minerals, display a wide range in size and abundance; some specimens are as much as 15 percent phenocrysts, whereas others are virtually nonprophyritic. Plagioclase phenocrysts as long as $40 \mathrm{~mm}$ have been noted, although this is exceptional. Degree of alteration of the rocks varies considerably; mafic minerals, except for the opaque oxides, have generally been altered beyond recognition. Carbonate, chlorite, epidote, and sericite are common alteration products. Pilotaxitic texture is common to all rocks from the mafic dikes. On the basis of densities and plagioclase compositions, the mafic dikes are considered to range in composition from andesite to basalt, although a single analyzed sample (table 6, No. 114) has an alkalic affinity.

\section{QUARTZ VEINS}

Two generations of steeply dipping northwesttrending quartz veins have been recognized in the Uyaijah ring structure.

Older, gashlike veins cut by the hypabyssal mafic dikes commonly occur in en echelon swarms concentrated in altered granite of Jabal Thaaban; alteration and injection of veins were not contemporaneous everywhere, as some veins cut bands of altered granite. Downdip-plunging slickensides on vein walls are common, indicating vertical movement along fractures subsequent to vein emplacement. The quartz in the veins is generally massive and milky to translucent, is occasionally granulated, and commonly bears disseminated pyrite and molybdenite.

Younger, singly occurring veins that cut mafic dikes are less common but far more widespread throughout the structure than the older veins. There is no evidence of subsequent movement along fractures occupied by the younger veins. The veins consist principally of massive milky quartz; comb and banded structures are common locally; sulfide minerals are rarely present.

\section{STRUCTURE AND EMPLACEMENT OF THE INTRUSIVE ROCKS}

Early-developed features of the Uyaijah ring structure itself, as well as the presence of other contemporaneous circular masses in the region, indicate that initial concentric form generally dominated tectonic evolution of the structure. Undoubtedly, some earlyformed structural elements, such as jointing associated with pluton emplacement, have been obliterated or modified by superposition of regional east-west to northwest-trending fractures late in the structure's history.
The primary foliations in the granodiorite of $\mathrm{Al}$ Areyef define a remarkably continous circular structure (fig. 6). The structure is funnel shaped, generally dipping vertically or steeply inward, except in the eastern part of the batholith, where it is less steeply inclined. Primary foliation is thought to originate from shear flow within a magma chamber or outward expansion of magma during crystallization, two theories reviewed by White (1973). Marked schistosity in metamorphic rocks parallel to the contacts with the granodiorite and elongation of metamorphic septa parallel to the granodiorite foliation indicate deformation by forcible batholithic emplacement. Most likely the funnel-shaped structure of the granodiorite batholith reflects a single event of shear flow from a locus of magmatic upwelling.

The nearly circular outline of the central stock of granite of Jabal Thaaban parallels the foliations of the granodiorite of $\mathrm{Al}$ Areyef, and the center of the stock nearly coincides with the locus of normals to the foliations (fig. 6); the stock is thus concordant with the older structure. In contrast, the southern boundary of the small eastern body of granite cuts foliations of adjacent rocks at nearly right angles and is discordant with the older structure. Presence of inclusions of the older granodiorite in the granite along the margin of the central stock suggests that stoping played a role in emplacement of the granite core.

The leucogranite of Jabal Abu Khurg was emplaced as a ring dike whose form was controlled by the older, preexisting circular structure. The presence of sill-like bodies of the granite on the convex side of the ring dike and their paucity on the concave side (pl.1) suggest that the inner part of the structure was a region of compression during dike intrusion, whereas the outer part was a region of distension, an expected condition if the dike were forcibly emplaced. Where exposed, the contact of the ring dike with older rocks is vertical or dips steeply inward, a feature common to both the contact and contiguous foliations.

Extrusive volcanic rocks are not exposed in the general region of the Uyaijah ring structure; they may have been completely eroded away. In configuration and size, however, the ring dike resembles previously described cauldrons, features described by Smith and Bailey (1968). The subsurface form of the Uyaijah ring structure is undoubtedly similar to that depicted by Smith and others (1961) for Valles-type calderas; that is, the inclination of the ring fracture and consequent dike is vertical or dips steeply inward. The Uyaijah ring structure is believed to be a plutonic analog of an epicontinental caldera. 

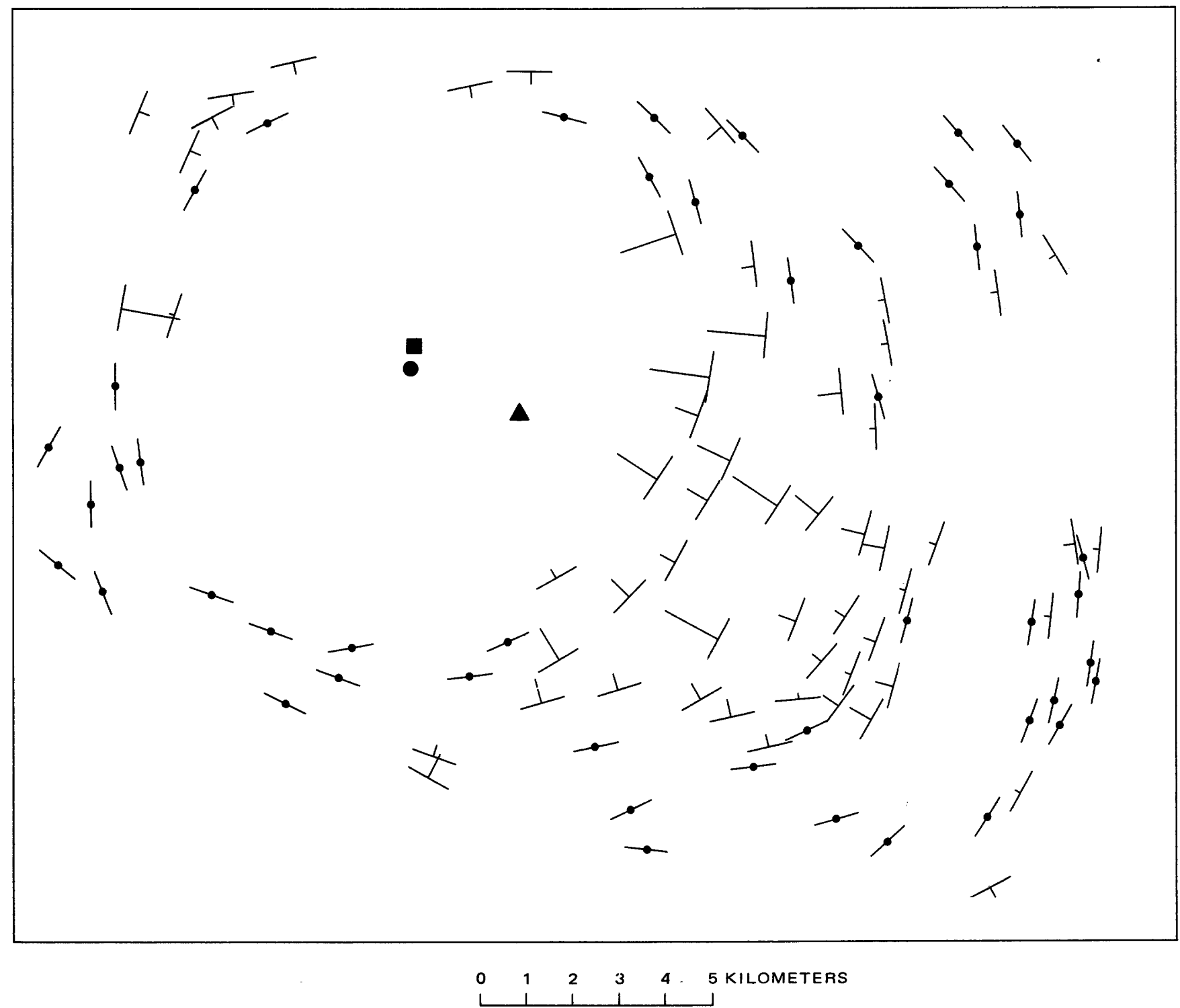

EXPLANATION

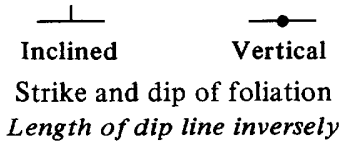
Length of dip line inversely proportional to dip
Center defined by primary foliations

Center of central core stock

\section{Projected center of ring dike}

Figure 6-Primary foliations in the granodiorite of $\mathrm{Al}$ Areyef.

Major faulting and jointing follows the regional northwest trend of the Najd fault system and was subsequent to development of the ring structure. In the southeastern part of the area (pl. 1), the ring dike has been offset three-quarters of a kilometer along a left- lateral fault. Some quartz veins were emplaced during fracturing; other veins and the dikes, which generally follow trends subparallel to joints and faults, postdate the period of major active faulting.

Minor late faults have been recognized at a few lo- 
calities. These faults, which have no apparent systematic trends, have lateral displacements of only a few meters and extend for short distances.

\section{CHEMISTRY AND EVOLUTION OF THE INTRUSIVE ROCKS}

Chemical data on intrusive rocks of the Uyaijah ring structure presented in tables $2,3,5$, and 6 are plotted as figures 7, 8, and 9. Chondrite-normalized rare-earth element (REE) patterns, derived using the average chondrite REE values quoted by Hermann (1970), are shown in figure 10. Selected elemental ratios are given in table 7 , in which the samples are arranged in order of decreasing age and, with exceptions of the dike rocks, increasing silica content.

In figure 7, the normative proportions of $\mathrm{Q}$, Or, and $\mathrm{Ab}$ of the analyzed plutonic rocks of the ring structure, shown together with their An contents normalized to 100 percent $\mathrm{Q}+\mathrm{Or}+\mathrm{Ab}+\mathrm{An}$, define a trend subparallel to the $\mathrm{Q}-\mathrm{Ab}$ sideline. All the plutonic rocks contain 90 percent or more normative $\mathrm{Q}+\mathrm{Or}+\mathrm{Ab}+\mathrm{An}$, and $\mathrm{Q}+\mathrm{Or}+\mathrm{Ab}$ is less than 80 percent of the total norm in only one rock; the greater part of the chemical variation is indicated in the figure. The samples of granodiorite of $\mathrm{Al}$ Areyef are generally nearest the $\mathrm{Ab}-\mathrm{Or}$ side and show the greatest scatter. An contents decrease toward the Q-Or side but with some irregularity. One of the analyses of the leucogranite of Jabal Abu Khurg contains 2.8 percent normalized An and lies very near the ternary minimum determined by James and Hamilton (1969) for compositions containing 3 percent $A n$ at a water-vapor pressure of 1 kilobar.

Plots of major-element oxides relative to age, shown in figure 8 , generally reveal a fairly great compositional range and well-defined gradational trends of the individual oxides of the plutonic rocks. $\mathrm{SiO}_{2}$ and $\mathrm{K}_{2} \mathrm{O}$ increase systematically from the granodiorite of Al Areyef, through the granite of Jabal Thaaban, to the leucogranite of Jabal Abu Khurg, whereas $\mathrm{Al}_{2} \mathrm{O}_{3}$, total $\mathrm{Fe}$ as $\mathrm{FeO}, \mathrm{MgO}, \mathrm{CaO}, \mathrm{TiO}_{2}$, and $\mathrm{P}_{2} \mathrm{O}_{5}$ all decrease systematically. $\mathrm{Na}_{2} \mathrm{O}$ shows no significant change in amount, and $\mathrm{MnO}$ exhibits considerable scatter and shows no clear trend.

Plots of minor elements, shown in figure 9, are more difficult to evaluate than the major-element oxide plots because of the limited number of minor-element analyses and the considerable scatter of the data. Those elements showing convincing systematic gradational changes are Sc, total $\mathrm{REE}, \mathrm{Cr}$, and $\mathrm{Co}$; all decrease from the granodiorite of $\mathrm{Al}$ Areyef to the leucogranite of Jabal Abu Khurg. Six elements (Rb, Cs, Ta, $\mathrm{Zr}, \mathrm{Hf}$, and $\mathrm{Sb}$ ) show only vaguely indicated or no convincing systematic trends. It is particularly notewor-

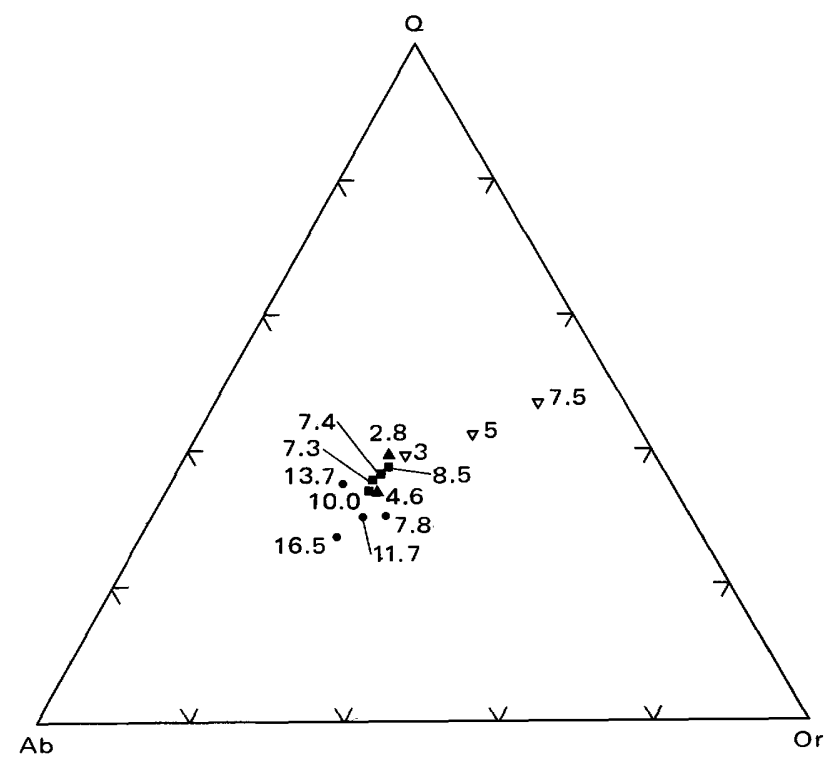

EXPLANATION

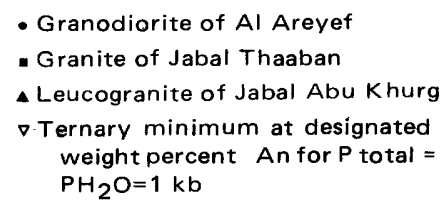

Figure 7.-Ternary diagram showing norms of analyzed plutonic rock samples from the Uyaijah ring structure. Ternary minimums from James and Hamilton (1969).

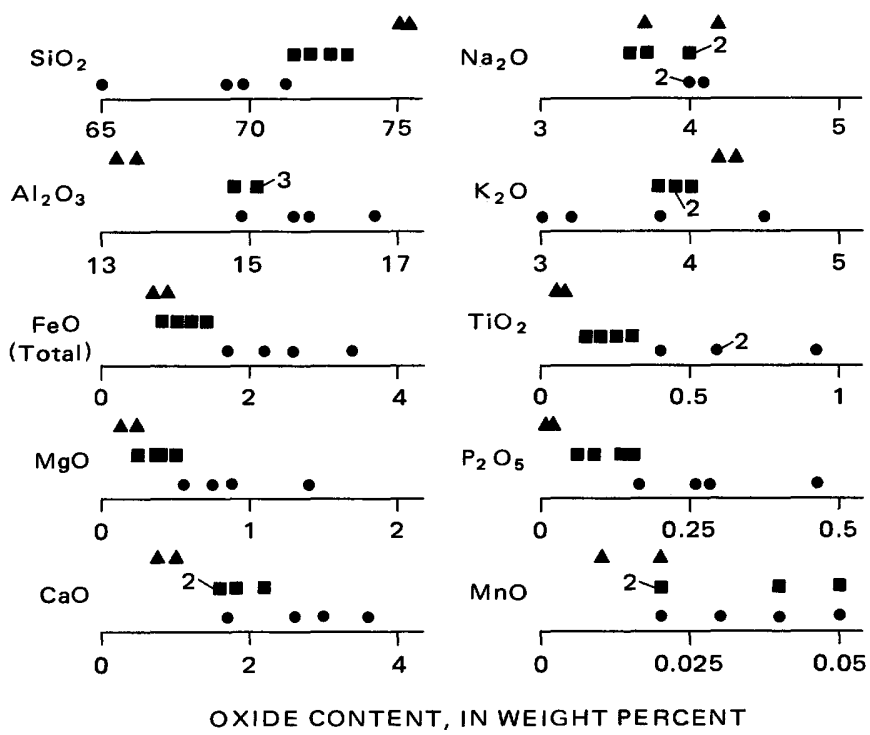

FigURE 8.-Major-element oxide contents (in weight percent) of the plutonic rocks of the Uyaijah ring structure. Number of values coinciding are noted. Symbols same as figure 7.

thy that $\mathrm{Sr}$ and $\mathrm{Ba}$ are present in extremely low amounts in the leucogranite of Jabal Abu Khurg. The average $\mathrm{Sr}$ value is approximately $460 \mathrm{ppm}$ (parts per million) in the granodiorite of $\mathrm{Al}$ Areyef and granite of 


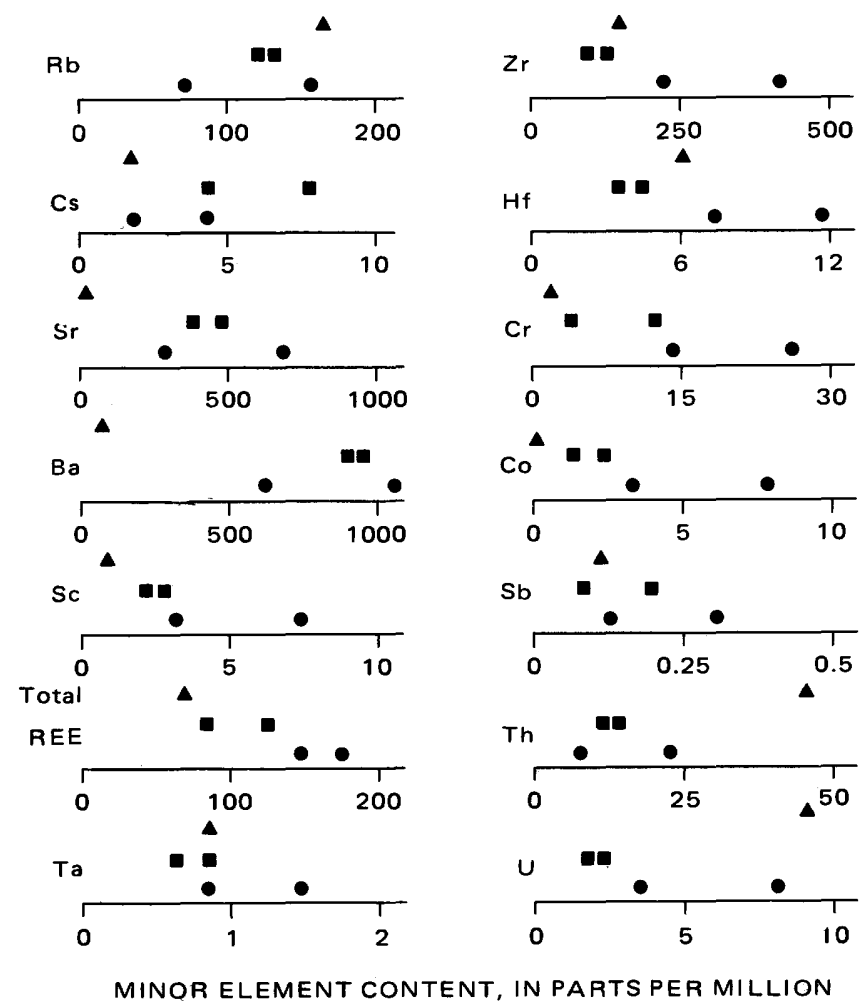

Figure 9.-Minor-element contents (in parts per million) of plutonic rocks of the Uyaijah ring structure. Symbols same as in figure 7 .

Jabal Thaaban, whereas the leucogranite of Jabal Abu Khurg contains only $21 \mathrm{ppm}$. Turekian and Wedepohl (1961) give average $\mathrm{Sr}$ values of 440 and $100 \mathrm{ppm}$ respectively for high- and low-calcium granites of the Earth's crust. Barium constitutes $78 \mathrm{ppm}$ in the leucogranite of Jabal Abu Khurg and averages 890 ppm in the other two rocks. Worldwide averages of 888 ppm Ba in high-calcium and $732 \mathrm{ppm}$ in low-calcium granitic rocks have been reported by Puchelt (1972). Thorium content of the leucogranite of Jabal Abu Khurg is more than twice that of the older granitic rocks and is considerably greater than averages for granitic rocks given by Heier and Rogers (1963) or by Clark and others (1966). Uranium content of the granite also is greater than in the older rocks, though not to the extent of thorium.

Differences in individual REE contents between the three granitic units are strikingly displayed by their chondrite-normalized REE patterns (fig. 10). The patterns for the two analyzed samples of the granodiorite of $\mathrm{Al}$ Areyef both have negative slopes common to many granitic rocks throughout the world (Koljonen and Rosenberg, 1974). Relative to chondrites, their light rare earths (LREE) are enriched roughly 100 times, and their heavy rare earths (HREE) 5 to 9 times. One of the granodiorite samples (No. 222) has a small negative Eu anomaly, whereas the other (No. 215) has a small positive anomaly. Rare-earth patterns of the granite of Jabal Thaaban are similar to patterns of the granodiorite but show somewhat less enrichment, LREE and HREE being enriched 85 and 2.5, respectively, relative to chondrites. Both patterns show slight, nearly insignificant, negative Eu anomalies. The REE pattern for the leucogranite of Jabal Abu Khurg is relatively flat overall, with LREE enriched approximately 25 times, but has an extremely large $\mathrm{Eu}$ anomaly. Configuration of the pattern is similar to the pattern shown by Bowden and Whitley (1974) for highlevel peralkaline granites of Nigeria, but absolute REE abundances are considerably lower.

Both analyzed late dike rocks have REE patterns with negative slopes. The mafic rock has a small positive Eu anomaly, the felsic rock, a moderately strong negative anomaly.

Commonly iterated ratios of geochemically coherent elements (table 7) amplify some of the differences in trace-element contents between the different rocks; values for $\mathrm{K} / \mathrm{Ba}, \mathrm{Rb} / \mathrm{Sr}, \mathrm{La} / \mathrm{Yb}, \mathrm{Eu} / \mathrm{Eu}$, ${ }^{*}$ and $\mathrm{Fe} / \mathrm{Co}$ differ strikingly in the leucogranite of Jabal Abu Khurg and the late felsic dike rock from ratios for the other rocks analyzed. Other elemental ratios generally differ somewhat less, although $\mathrm{K} / \mathrm{Rb}$ in the felsic dike rock and $\mathrm{Ba} / \mathrm{Sr}$ in the mafic dike rock are considerably lower than in the other rocks.

The large negative Eu anomalies in the felsic dike rock and the leucogranite of Jabal Abu Khurg and the similarity in their elemental ratios suggest the two may be closely related.

Initial ${ }^{87} \mathrm{Sr} /{ }^{86} \mathrm{Sr}$ of granodiorite to granite plutons in the Arabian Shield south of the Uyaijah ring structure that are probably correlative with the granodiorite of Al Areyef and granite of Jabal Thaaban generally are between 0.703 and 0.704 (R. J. Fleck, written commun., 1977), implying a sialic crustal source. Zielinski and Lipman (1976) interpreted similar REE patterns of silicic volcanic rocks from the continental Summer Coon volcano as resulting from production of secondary magma by low-pressure fractional crystallization of plagioclase and hornblende from andesite magma, which in turn was derived by voluminous partial melting of high-pressure eclogitic equivalents of crustal rocks, leaving a garnet-clinopyroxene residue. The grandiorite of $\mathrm{Al}$ Areyef may have been generated from an analogous source by upwelling of fractionated magma.

The progression from granodiorite to granite intrusives with decreasing age implies further evolution by crystal fractionation rather than by differing degrees of partial melting of source material. Possible minor contamination by preintrusive metasedimentary rocks 

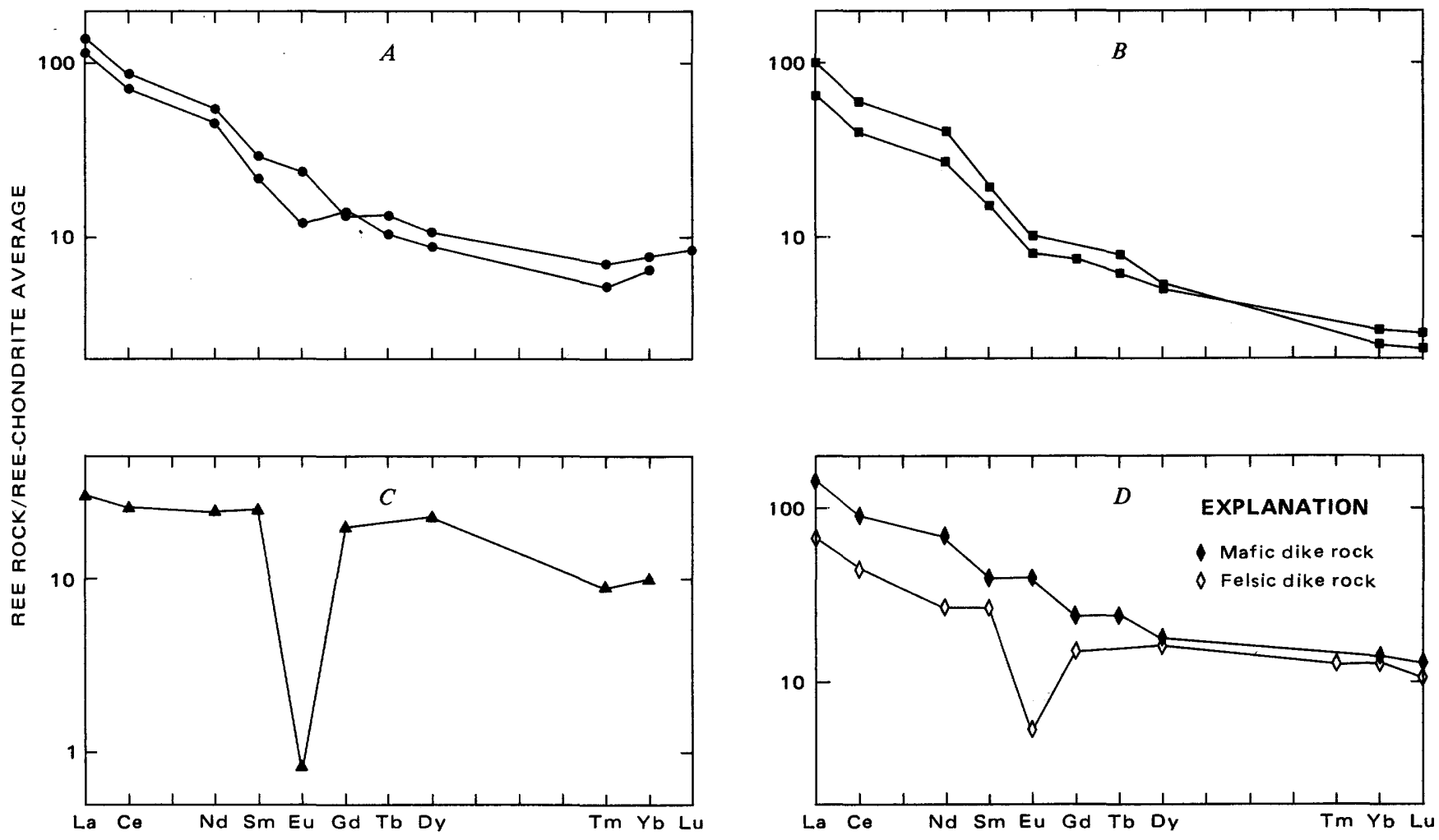

FIGURE 10.-Chondrite-normalized rare-earth elements (REE) of igneous rocks of the Uyaijah ring structure. $A$, Granodiorite of Al Areyef. $B$, Granite of Jabal Thaaban. $C$, Leucogranite of Jabal Abu Khurg. $D$, Felsic and mafic dike rocks.

(table 1) may be responsible for scatter in trends of major elements and normative constituents, although the scatter may be simply due to analytical error. The compositional variations between the granodiorite and granite, particularly the slight differences in the REE patterns and in $\mathrm{Sc}, \mathrm{Cr}$, and Co contents, have been largely produced by continued fractional crystallization and removal of liquidus-phase hornblende from grandiorite magma during evolution of granite magma.

If the leucogranite of Jabal Abu Khurg was derived from the same parent magma as the granite and granodiorite by continued differentiation, as suggested by the normative and major-element trends, the rela- tively flat REE pattern and large negative Eu anomaly of the leucogranite indicate a sharp change in the differentiation process. LREE depletion could have been the result of fractionation and removal of an LREEenriched, but unknown, minor phase, such as allanite or chevkinite (Barker and others, 1976). Depletion of REE by fractionation of common REE-bearing accessory minerals followed by reintroduction of HREE by volatile transfer is a second, liklier possibility for generation of the flat leucogranite REE pattern. $\mathrm{TiO}_{2}$ and $\mathrm{P}_{2} \mathrm{O}_{5}$ contents of the leucogranite are lower than those of the granite or granodiorite, suggesting that both apatite and sphene were separated from the parent magma. The pinkish hue and presence of thin oxide

TABLE 7.-Selected elemental ratios of igneous rocks of the Uyiajah ring structure based on neutron activation analysis $\left[\mathrm{Eu} / \mathrm{Eu}^{*}\right.$ determined from chondrite normalized REE plots]

\begin{tabular}{|c|c|c|c|c|c|c|c|}
\hline \multirow[b]{2}{*}{ Sample No. } & \multicolumn{2}{|c|}{$\begin{array}{l}\text { Granodiorite of } \\
\text { Al Alreyef }\end{array}$} & \multicolumn{2}{|c|}{$\begin{array}{c}\text { Granite of Jabal } \\
\text { Thaaban }\end{array}$} & \multirow{2}{*}{$\begin{array}{c}\begin{array}{c}\text { Leucogranite of } \\
\text { Jabal Abu Khurg }\end{array} \\
018\end{array}$} & \multicolumn{2}{|c|}{\begin{tabular}{cc}
\multicolumn{2}{c}{ Dike rocks } \\
Felsic
\end{tabular}} \\
\hline & 215 & 222 & 535 & 121 & & 096 & 114 \\
\hline $\begin{array}{l}\mathrm{K} / \mathrm{Na} \\
\mathrm{K} / \mathrm{Rb} \\
\mathrm{K} / \mathrm{Cs} \\
\mathrm{K} / \mathrm{Ba} \\
\mathrm{Rb} / \mathrm{Sr} \\
\mathrm{Ba} / \mathrm{Sr} \\
\mathrm{La} / \mathrm{Yb} \text { - } \\
\mathrm{E} / \mathrm{Eu}^{*} \mathrm{~d} \\
\mathrm{Zr} / \mathrm{Hf} \\
\mathrm{Fe} / \mathrm{Sc} \\
\mathrm{Fe} / \mathrm{Co} \\
\mathrm{Th} / \mathrm{U}\end{array}$ & $\begin{array}{c}.076 \\
360 \\
13,300 \\
23.9 \\
.10 \\
1.53 \\
30.3 \\
1.18 \\
36.8 \\
3,260 \\
3,090 \\
2.09\end{array}$ & $\begin{array}{c}1.17 \\
222 \\
8,200 \\
55.6 \\
.53 \\
2.13 \\
30.2 \\
.74 \\
30.7 \\
3,720 \\
3,440 \\
2.70\end{array}$ & $\begin{array}{c}1.11 \\
282 \\
7,950 \\
35.9 \\
.25 \\
1.98 \\
70.2 \\
.82 \\
31.0 \\
3,497 \\
4,010 \\
7.36\end{array}$ & $\begin{array}{c}1.13 \\
259 \\
4,450 \\
36.5 \\
.34 \\
2.40 \\
38.5 \\
.79 \\
28.7 \\
3,010 \\
5,150 \\
5.48\end{array}$ & $\begin{array}{c}1.18 \\
226 \\
21,900 \\
483 \\
8.06 \\
3.78 \\
4.93 \\
.04 \\
25.3 \\
6,310 \\
25,700 \\
4.92\end{array}$ & $\begin{array}{c}1.48 \\
151 \\
9,870 \\
172 \\
4.32 \\
3.79 \\
9.18 \\
.26 \\
27.3 \\
3,700 \\
12,100 \\
2.72\end{array}$ & $\begin{array}{c}0.59 \\
216 \\
2,710 \\
27.1 \\
.09 \\
.70 \\
17.8 \\
1.36 \\
42.9 \\
5,720 \\
2,370 \\
3.47\end{array}$ \\
\hline
\end{tabular}


films in the leucogranite and sericitic alteration of the granite of Jabal Thaaban indicate activity of late-stage hydrothermal fluids in the Uyaijah structure. Kosterin (1959) and Buma and others (1971) noted that HREE form more stable complexes than LREE and consequently become relatively enriched in hydrothermal solutions. Bowden and Whitley (1974) proposed that an upward curvature of HREE in chondrite-normalized REE patterns of Nigerian syenites and granites was attributable to a residual hydrothermal volatile-rich fluid autometasomatizing the partly crystalline rocks and progressively obliterating earlier magmatic REE patterns.

The large negative Eu anomaly of the leucogranite of Jabal Abu Khurg suggests that rather great amounts of feldspar may have fractionated from magma from which the leucogranite crystallized. The extremely.low contents of both $\mathrm{Sr}$ and $\mathrm{Ba}$, which are concentrated in plagioclase feldspar and potassium feldspar respectively (Nagasawa and Schnetzler, 1971; Puchelt, 1972), indicate that the magma was depleted in both feldspars, and, together with the major-element composition, suggest that the leucogranite crystallized from a melt of ternary composition at water-vapor pressures of about 1 kilobar (fig. 7), or assuming water saturation, at depths of approximately $3 \mathrm{~km}$. This rather shallow depth is expectable if the ring structure is the plutonic analog of an epicontinental caldera.

Alternatively, the leucogranite may have been derived from an unknown source independent of the parental magma of the earlier rocks. In this case, only subordinate amounts of garnet, pyroxene, or hornblende could have been involved in generation of leucogranite magma. Hildreth (1976) has postulated that REE patterns of the Bishop Tuff of the Long Valley caldera, similar to the pattern of leucogranite, formed as a result of a differentiation mechanism combining progressive partial melting with convection-assisted liquid-state diffusion controlled by complexing and thermogravitational potentials and did not involve crystal settling.

LREE enrichment of the mafic dike rock is typical of alkali-rich basalts (Schilling, 1972). Trace elements of the rock do not suggest any relation between the mafic dikes and other units of the ring structure.

\section{SUMMARY}

Form of the Uyaijah ring structure was controlled by the early-formed foliation developed in the rather deeply generated host batholith, as shown by schematic section in figure 11. Continuous differentiation of the batholithic magma resulted in production of the central core stock that was stoped into the batholith. The granitic ring dike, which crystallized from melt of ter-

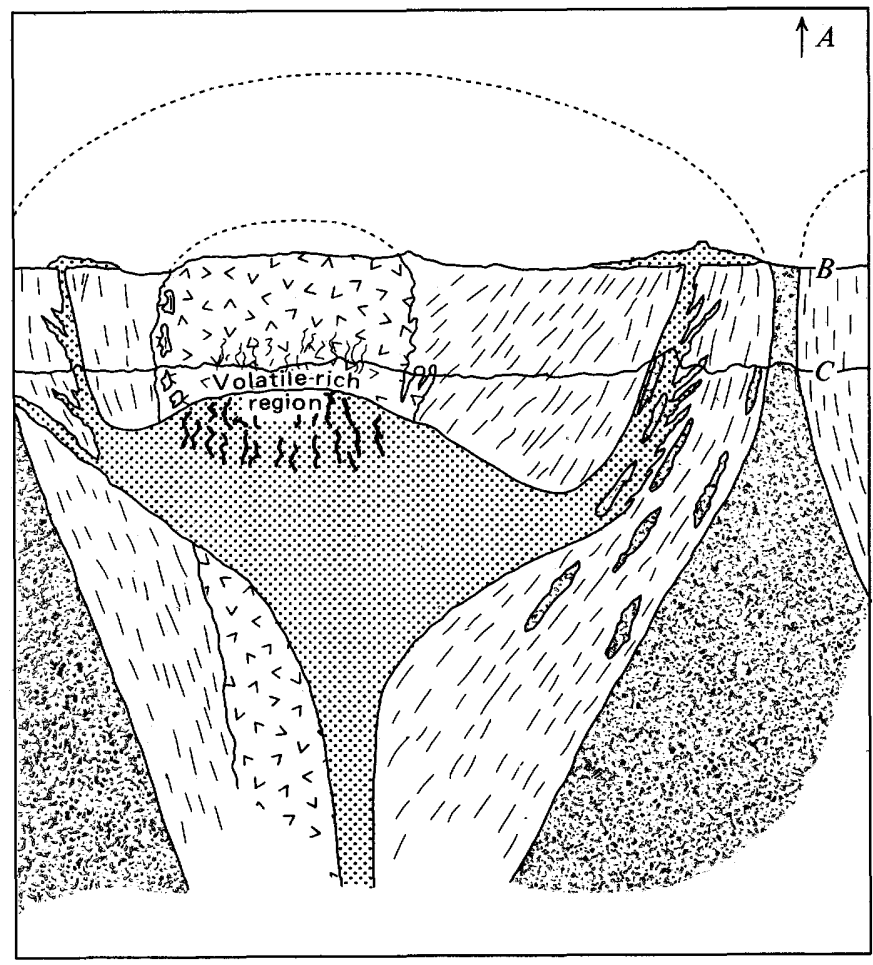

EXPLANATION

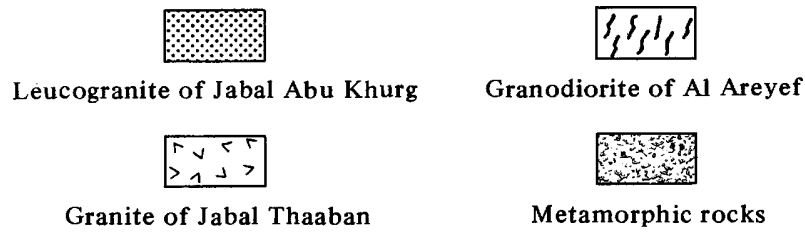

Figure 11.-Schematic section showing development of the Uyaijah ring structure. $A$, Surface at time of emplacement of the granodiorite of $\mathrm{Al}$ Areyef; $B$, Surface at time of emplacement of the leucogranite of Jabal Abu Khurg; $C$, Present-day surface. No vertical exaggeration.

nary minimum composition at shallow depths, was forcibly emplaced into the batholith. Although related extrusive volcanic rocks are not exposed in the general region, the ring structure is believed to be the plutonic analog of an epicontinental caldera.

\section{REFERENCES CITED}

Barker, Fred, Hedge, C.E., Millard, H. T., Jr., O’Neil, J. R., 1976, Pikes Peak batholith-geochemistry of some minor elements and isotopes, and implications for magma genesis, in Epis, R. C., and Weimer, R. J., eds., Studies in Colorado field geology: Colorado School Mines Prof. Contr. 8, p. 44-56.

Bowden, P., and Whitley, J. E., 1974, Rare-earth pattern in peralkaline and associated granites: Lithos, v. 7, p. 15-21.

Brown, G. F., and Jackson, R. O., 1960, The Arabian Shield: Internat. Geol. Cong., 21st, Copenhagen 1960, pt. 9, p. 69-77.

Buma, Grant, Frey, F. S., and Wones, D. R., 1971, New England granites-trace element evidence regarding their origin and differentiation: Contr. Mineralogy and Petrology, v. 31, p. $300-320$. 
Bussell, M. A., Pitcher, W. S., and Wilson, P. A., 1976, Ring complexes of the Peruvian coastal batholith-a long-standing subvolcanic regime: Canadian Jour. Earth Sci., v. 13, p. 1020-1030.

Chapman, R. W., 1942, Ring structures of the Pliny region, New Hampshire: Geol. Soc. America Bull., v. 53, p. 1533-1568.

Clark, S. R., Jr., Peterman, Z. E., and Heier, K. S., 1966, Abundances of uranium, thorium, and potassium, in Clark, S. P., Jr., ed., Handbook of physical constants: Geol. Soc. America Mem. 97, p. 521-541.

Delfour, J., 1970, Le Groupe de J'balah, une nouvelle unite du bouclier arabe: [France] Bur. Rechèrches Géol. et Minieres Bull., sér. 2 , sec. 4 , no. 5 , p. 19-32.

Dodge, F. C. W., 1973, Geology and evaluation of tungsten anomalies, Buhairan-Abu Khurg area, southeastern part of the Uyaijah ring structure, Kingdom of Saudi Arabia: U.S. Geol. SurveySaudi Arabian Proj. Rept. 163, 32 p.

Dodge, F. C. W., and Helaby, A. M., 1975, Mineralization in the Uyaijah-Thaaban area, west-central part of the Uyaijah ring structure, Kingdom of Saudi Arabia: U.S. Geol. Survey OpenFile Rept, (IR) SA-191, 43 p.

Eggler, D. H., 1968, Virginia Dale Precambrian ring-dike complex, Colorado-Wyoming: Geol. Soc. America Bull., v. 79, p. 1545-1564.

Flanigan, V. J., and Andreasen, G. E., 1975, Tungsten anomalies in the Uyaijah ring structure, Section B-Regional geophysics: U.S. Geol. Survey Open-File Rept. (IR) SA-160, p. 67-86.

Fleck, R. J., Coleman, R. G., Cornwall, H. R., Greenwood, W. R., Hadley, D. G., Schmidt, D. L., Prinz, W. C., and Ratté, J. C., 1976, Geochronology of the Arabian Shield, western Saudi Arabia-K-Ar results: Geol. Soc. America Bull., v. 87, p. 9-21.

Gordon, G. E., Randle, K., Goles, G. G., Corliss, J. B., Beeson, M. H., and Oxley, S. S., 1968, Instrumental activation analysis of standard rocks with high resolution $\delta$-ray detectors: Geochim. et Cosmochim. Acta, v. 32, p. 369-396.

Greenwood, W. R., and Brown, G. F., 1973, Petrology and chemical analyses of selected plutonic rocks from the Arabian ShieldKingdom of Saudi Arabia: Saudi Arabian Dir. Gen. Mineral Resources Bull. 9, 9 p.

Heier, K. S., and Rogers, J. J. W., 1963, Radiometric determinations of thorium, uranium and potassium in basalts and in two magmatic differentiation series: Geochem. et Cosmochim. Acta, v. 27 , p. $137-154$.

Hermann, A. G., 1970, Yttrium and lanthides, in Wedepohl, K. H., ed., Handbook of geochemistry, V. 2: Berlin, Springer-Verlag, p. $39,57-71-B-1$ to $39,57-71-0-9$.

Hertogen, J., and Gijbels, R., 1971, Instrumental neutron activation analysis of rocks with a low-energy photon detector: Anal. Chim. Acta., v. 56 , p. $61-82$.

Hildreth, Wes, 1976, The Bishop Tuff-compositional zonation in a silicic magma chamber without crystal setting: Geol. Soc. America Abs. with Programs, v. 8, no. 6, p. 918.

Jackson, E. D., and Ross, D. C., 1956, A technique for modal analysis of medium- and coarse-grained (3-10 mm) rocks: Am. Mineralogist, v. 41, p. 648-651.

Jackson, R. O., Bogue, R. G., Brown, G. F., and Gierhart, R. D., 1963, Geologic map of the Southern Najd quadrangle, Kingdom of Saudi Arabia: U.S. Geol, Survey Misc. Geol. Inv. Map I-211A, scale 1:500,000.

Jacobson, R. R. E., MacLeod, W. M., and Black, Russell, 1958, Ringcomplexes in the younger granite province of northern Nigeria: Geol. Soc. London Mem. 1, 72 p.

James, R. S., and Hamilton, D. L., 1969, Phase relations in the system $\mathrm{NaAlSi}_{3} \mathrm{O}_{8}-\mathrm{KAlSi}_{3} \mathrm{O}_{8}-\mathrm{CaAl}_{2} \mathrm{Si}_{2} \mathrm{O}_{8}-\mathrm{SiO}_{2}$ at 1 kilobar water vapour pressure: Contr. Mineralogy and Petrology, v. 21, p. 111141.

Koljonen, T., and Rosenberg, R. J., 1974, Rare earth elements in granitic rocks: Lithos, v. 7, p. 249-261.
Kosterin, A. V., 1959, The possible modes of transport of the rare earths by hydrothermal solutions: Geochemistry, no. 4, p. 381-387.

Lacombe, P., and Letalenet, J., 1970, Mineral resources and geology of the Jabal al Hawshaw quadrangle-Sheet 129E-Zone 2: Bur. Recherches Géol. et Minierès Rept. 70JED26, 32 p.

Laniz, R. V., Stevens, R. E., and Norman, M. B., 1964, Staining of plagioclase feldspar and other minerals with F. D. and C. Red No. 2: U.S. Geol. Survey Prof. Paper 501-B, p. B152-B153.

Meyer, Charles, and Hemley, J. J., 1967, Wall rock alteration, in Barnes, H. L., ed., Geochemistry of hydrothermal ore deposits: New York, Holt, Rinehart and Wilson, p. 166-235.

Nagasawa, Hiroshi, and Schnetzler, C. C., 1971, Partitioning of rare earth, alkali and alkaline earth elements between phenocrysts and acidic igneous magma: Geochim. et Cosmochim. Acta, v. 35, p. 953-968.

Neary, C. R., Gass, I. G., and Cavanaugh, B. J., 1976, Granitic association of northeastern Sudan: Geol. Soc. America Bull., v. 87, p. 1501-1512.

Oftedahl, Christoffer, 1953, Studies on the igneous rock complex of the Oslo region XIII, The cauldrons: Norske Vidensk.-Akad. Oslo Skr., Mat.-Naturv. Kl., no. 3, 108 p.

Oldershaw, W., 1974, The Lochnagar granitic ring complex: Scottish Jour. Geology, v. 10, p. 297-309.

Puchelt, H., 1972, Barium, in Wedepohl, K. H., ed., Handbook of geochemistry, V. 2: Berlin, Springer-Verlag, p. 56-B-1 to 56-O-22.

Rittman, Alfred, 1952, Nomenclature of volcanic rocks: Bull. Volcanol., ser. 2, v. 12 , p. 75-102.

Schilling, J-G., 1972, Rare earths in basalts, in Fairbridge, R. W., ed., The encyclopedia of geochemistry and environmental sciences, V. 4A: New York, Van Nostrand Reinhold Co., p. 1029-1039.

Schmidt, D. L., Hadley, D. G., Greenwood, W. R., Gonzalez, Louis, Coleman, R. G., and Brown, G. F., 1973, Stratigraphy and tectonism of the southern part of the Precambrian Shield of Saudi Arabia: Saudi Arabian Dir. Gen. Mineral Resources Bull. 8, 13 p.

Shapiro, Leonard, and Brannock, W. W., 1962, Rapid analysis of silicate, carbonate, and phosphate rocks: U.S. Geol. Survey Bull. 1144-A, 55 p.

Smith, R. L., and Bailey, R. A., 1968, Resurgent cauldrons, in Coats, R. R., Hay, R. L., and Anderson, C. A., eds., Studies in volcanology: Geol. Soc. America Mem. 116, p. 613-662.

Smith, R. L., Bailey, R. A., and Ross, C. S., 1961, Structural evolution of the Valles caldera, New Mexico, and its bearing on the emplacement of ring dikes: U.S. Geol. Survey Prof. Paper 424-D, p. D145-D149.

Theobald, P. K., 1971, Al Kushamiyah as a target for a Coloradotype molybdenite deposit, Southern Najd quadrangle, Kingdom of Saudi Arabia: U.S. Geol. Survey Open-File Rept. (IR) SA-120, $13 \mathrm{p}$.

Theobald, P. K., and Allcott, G. H., 1975, Tungsten anomalies in the Uyaijah ring structure, Section A-Geology and geochemistry of the Uyaijah ring structure: U.S. Geol, Survey Open-File Rept. (IR) SA-160, p. 1-66.

Turekian, K. K., and Wedepohl, K. H., 1961, Distribution of the elements in some units of the earth's crust: Geol. Soc. America Bull., v. 72, p. 175-192.

Vail, J. R., 1972, A ring complex igneous province in northern Sudan, in Dessauvagie, T. F. J., and Whitman, A. J., eds., Proceedings of the Conference of African Geology: Ibadan, Nigeria, Ibadan Univ., p. 163-177.

White, W. H., 1973, Flow structure and form of the Deep Creek stock, southern Seven Devils Mountains, Idaho: Geol. Soc. America Bull., v. 84, p. 199-210.

Whitlow, J. W., 1968a, Geology and geochemical reconnaissance of the Jabal Al Hawshah quadrangle, southern Najd: Saudi Arabian Dir. Gen. Mineral Resources Min. Inv. Map MI-16. 
1968b, Geology and geochemical reconnaissance of the $\mathrm{Al}$ Kushamiyah quadrangle, southern Najd: Saudi Arabian Dir. Mineral Resources Min. Inv. Map MI-17.

-1971, Areas in the southern Najd quadrangle, Saudi Arabia, recommended for mineral investigation: U.S. Geol. Survey
Open-File Rept. (IR) SA-79, 11 p.

Zielinski, R. A., and Lipman, P. W., 1976, Trace-element variations at Summer Coon volcano, San Juan Mountains, Colorado, and the origin of continental interior andesite: Geol Soc. America Bull., v. 87, p. $1477-1485$. 
$\cdots$ 
